\title{
Financial openness, disclosure and bank risk-taking in MENA countries.
}

\author{
Arnaud Bourgain $\dagger$ Patrice Pieretti $;$ Skerdilajda Zanaj ${ }^{\S}$ \\ University of Luxembourg, CREA
}

January 2012

\begin{abstract}
In this paper, we analyze the risk-taking behavior of banks in emerging economies in a context of international capital mobility. Our paper highlights a new channel through which depositors can exercise pressure to control risk-taking. Depositors can reallocate their savings away from their home country to the more protective system of a developed economy. We recover a classical result according to which increased competition resulting from more international financial openness induces banks to take excessive risks. We find however that sufficiently high financial openness is necessary for a positive link between financial transparency and safe risk management. Finally, we test the relationship between disclosure, financial openness and bank risk-taking for a panel of 258 banks from the MENA region and Turkey.
\end{abstract}

Keywords: banking competition, disclosure, bank risk-taking, MENA banking sectors, mock compliance

JEL Classification: G21, G28, F39, L80

*We acknowledge useful comments to Donato Masciandaro, Paolo Garella, Jean Gabszewicz, Gwenael Piaser, Michel Beine and to all participants of the CAE conference 2010, DREEM conference 2010 and Aixen Provence International Workshop 2011. We thank Deborah Schwartz for research assistance. The usual disclaimer applies.

†Corresponding author: arnaud.bourgain@uni.lu. Address: 162A, avenue de la Faiencerie, L-1511, Luxembourg.

${ }^{\ddagger}$ Email: patrice.pieretti@uni.lu.

§Email: skerdilajda.zanaj@uni.lu. 


\section{Introduction}

Efficient risk management in the banking sector is crucial for emerging economies. ${ }^{1}$ Because of their highly uncertain environment, these countries are prone to information problems that can cause excessive risk-taking behavior in the banking industry (Vives, 2006). This situation is further aggravated by the minimal development of their financial markets, which increases the role of banks. The intent of emerging countries to comply with advanced risk management procedures is nevertheless quite remarkable ${ }^{2}$. In 2009, 14 countries, some of which were large emerging countries, became members of the Basel Committee. According to many authors (Powell 2002, Fischer 2002, Llewellyn 2003, Balin 2008), however, the banking systems in emerging economies can face difficulties when adopting the sophisticated approaches initially that are intended, at least initally, for advanced economies. These authors highlight the structural weaknesses of the financial environment in emerging economies as captured by the low quality of accountancy data, a lack of auditing agencies, problems in accounting and auditing procedures and problems in implementing sophisticated risk measurement systems. Among emerging economies, the MENA (Middle East and Northern Africa) countries and Turkey are particularly interesting. Banking sectors in the MENA region are among the deepest in the emerging and developing world ${ }^{3}$. These sectors have undergone a profound transformation through a privatization process and the entry of foreign institutions, but some of them are still in the early stages of financial development and have a weak legal and supervisory environment (Anzoategui et al. 2010, Cigogna 2009). In a recent study of the banking sectors in the MENA region, Turk-Ariss (2009, p. 694) notes, "Monetary authorities in MENA countries generally require banks to adopt international accounting standards and to comply with international regulatory requirements." The stability of the banking sectors in this region is viewed as a condition of the attractiveness of

\footnotetext{
${ }^{1}$ In this paper, the term "emerging economies" does not refer to a specific list of countries. Each international organization or rating agency uses its own classification. Due to the lack of a precise definition, we consider emerging economies to be developing countries that are not part of the "Least Developed Countries" group. Our model is adapted to economies characterized by increasing financial integration as well as by a weak financial environment and capital flight.

${ }^{2}$ The 2008 FSI survey (FSI-BIS 2008, p. 2) indicates that 92 non-members of the Basel Committee on Banking Supervision have implemented or are currently planning to implement Basel II. Moreover, $61 \%$ of these non-members intend to offer the Advanced Internal Ratings Based Approach (Advanced IRB).

${ }^{3}$ The MENA region ranks second (behind East Asia) in banking sector development, according to the ratio of bank assets to GDP and the level of banking sector credit offered to the private sector as a ratio of GDP over the period 2002-2008 (Anzoategui et al., 2010).
} 
oil surplus funds.

In this paper, we analyze how international competition for deposits can prevent excessive bank risk-taking in emerging economies. In particular, we model pressure on the emerging banking system from possible capital outflows to a developed financial center. The quality of the financial environment is addressed by introducing the notion of transparency, defined as the ability of depositors to observe how prudently banks behave.

Our approach is motivated by an increasing degree of openness in emerging economies towards OECD countries. A higher level of openness translates into higher levels of capital mobility. It follows that banks must compete with those in developed countries to keep their depositors domestic ${ }^{4}$. For example, the Swiss private banking industry intends to attract a share of the increasing capital flows from the Middle-East, more than $50 \%$ of which are already managed by international banking centers ${ }^{5}$. Capital flight, which is particularly high from resource-based MENA economies (Almansour 2008), can furthermore be viewed as international competition for deposits. Among the various determinants of capital flight, there is evidence of a lack of confidence in the banking systems of East Asian economies or of countries such as Russia (Collier et al. 1999, Loungani and Mauro 2000, Perotti 2002), which have been hit by financial distress.

In this paper, we consider international banking competition as a disciplinary device. Depositors can exert pressure on home banks by reallocating their savings to an external (i.e., foreign) banking system that is more protective. The disciplinary role of depositors on banks has been studied by Calomiris and Kahn (1991), Allen and Gale (1999), Chen (1999) and, from a critical point of view, Hellwig (2005). The existing literature argues that depositors can punish banks by withdrawing their funds when they do not approve of the bank's behavior. This means of exerting discipline through the depositors' behavior is well documented empirically in emerging economies. These studies test the reaction of the depositors to high risk-taking on the banks' part by analyzing changes in the volume of deposits and the corresponding interest rates. In Latin America, empirical evidence has been found by Barajas and Steiner (2000) for Colombia, by Calomiris and Powell (2001) for Argentina, and by Martinez-Peria and Schmukler (2001) for Argentina, Mexico, and Chile.

\footnotetext{
${ }^{4}$ The increasing financial openness of emerging economies and its consequences have been well measured by Prasard et al. (2003). With the exception of FDIs, capital has tended to flow from poor to rich countries during the 2000s (Prasad et al. 2006).

${ }^{5}$ Swiss Bankers Association and Boston Consulting Group, Banking im Wandel-Zukunftsperspektiven für Banken in der Schweiz, Sept 2011.
} 
More recently, Ungan et al. (2008) have shown that deposits significantly increase with the improvement of capital and liquidity ratios in Russia. Similar evidence has also been found by Onder and Ozyildirim (2008) for Turkey.

It is generally argued that the effectiveness of this disciplining behavior crucially depends on the transparency of the banking system. It has also been suggested that bank regulation should impose greater transparency to mitigate moral hazards and reduce risk-taking (Bhattacharya, Boot and Thakor, 1998; Boot and Thakor, 2001; Admati and Pfleiderer, 2000; Cordella and Yeyati, 2002). Our paper specifically studies the interaction between transparency in bank risk-taking and the disciplinary role of depositors.

The main theoretical results of this paper can be summarized as follows. In our model, which has been adapted to emerging countries, we obtain a classical result according to which the increased competition that results from more international financial openness induces banks to take excessive risks. We find, however, that sufficiently high financial openness is necessary to achieve a positive link between financial transparency and safe risk management. In fact, augmenting transparency has an ambiguous effect. On the one hand, it makes banks more attractive to depositors due to higher information disclosure, but on the other hand it spurs competition and reduces bank profitability. When there is a high degree of financial openness, profit margins are relatively low and strong financial disclosure leads to weak losses. It then follows that the attractiveness effect of transparency dominates, which encourages banks to adopt safe risk management policies. The implication from the policy analysis perspectiven is that promoting successful financial disclosure in an emerging country requires sufficient financial openness.

The theoretical literature that is closest to our model is Cordella and Yeyati (2002) and Hyytinen and Takalo (2002).

Cordella and Yeyati (2002) develop a model of spatial competition among banks and study the impact of the dissemination of financial information and the entry of new banks on risk-taking. Differently from Cordella and Yeyati (2002), our paper is concerned with bank competition between countries at different stages of economic development and the impact of potential capital flight on risk-taking in the emergent countries. The method Cordella and Yeyati use to model financial transparency also differs from ours. Similar to Schultz (2004), we account for transparency by introducing both informed and uninformed investors.

Hyytinen and Takalo (2002) argue that the transparency required by bank regulation comes at a cost, which in turn can reduce the charter value of banks and increase the fragility 
of the banking system. Our model shows a similar result but for quite different reasons.

Finally, after calculating a bank disclosure index that was adopted from Baumann and Nier (2004), we empirically test the impact of financial openness and disclosure on bank risk-taking. Our empirical analysis is applied to Middle Eastern and North African (MENA) economies and to Turkey. For these countries, we collected individual financial data for 258 banks over the period from 2005-2008. Many economies in this region have experienced financial liberalization (Crean et al. 2007), and some of them are characterized by a massive capital flight (Almansour 2008). In line with Nier and Baumann (2006) and Demirgüç Kunt et al. (2008), our results confirm the negative relationship between transparency and various risk-taking indicators. In light of our theoretical model, this result indicates that the countries in our sample are on average characterized by a sufficiently high degree of financial openness. Moreover, our regressions show that the financial openness of emerging countries positively impacts risk-taking.

This paper is organized as follows. Section 2 presents the model and discusses the behavior toward risk of the banking systems in emerging countries. Empirical evidence on MENA countries is presented in Section 3.

\section{The Model}

Consider two countries $h$ and $f$, where $h$ is the emerging country and $f$ is the developed one. Each country contains one banking system ${ }^{6}$. We assume that the emerging country is not attractive to investors in country $h$. This assumption appears realistic enough because weak investor protection prevails in developing countries, as explained above. Therefore, depositors in the emerging region may decide to invest their savings in the developed country.

The population of investors located in the emerging country is portrayed by a linear segment $[0,1]$. The border of the emerging country is situated at position 1 and the domestic and foreign banking systems are located on the extremities 0 and 1, respectively. Depositors are uniformly distributed with density 1 along the linear segment $[0,1]$. This spatial representation must not be interpreted geographically. It is rather destined to capture the fact that depositors have idiosyncratic preferences in their attitudes toward foreign investments. More precisely, the closer the investor of type $x(x \in[0,1])$ is to the origin 0 , the more she favors

\footnotetext{
${ }^{6}$ Because we focus on international bank competition, we assume that the banking system in each jurisdiction reduces to one bank.
} 
its home financial center, but the closer she is to the border, the more willing she becomes to use cross-border deposits. Consequently, a depositor of type $x$ whose distance to the border is $1-x$ incurs a total transaction cost of $(1-x) k$. The lower the international mobility, the higher the unit cost $k$ will be. Hence $k$ can be viewed as a measure of the degree of international financial openness.

BANKS Banks offer an interest rate $r_{i}(i=h, f)$ to depositors and lend the deposited funds out to borrowers. Like Chiesa (2001), we assume that lending consists of project financing. A bank is presumed to take excessive risks if it does not monitor the funded project. Because we focus on the potential risk behavior within the emerging country, we assume, without loss of generality, that banks in the developed country do not take excessive risks ${ }^{7}$. More precisely, the bank in $h$ chooses strategy $s \in\{m, M\}$, where $s=m$ stands for "excessive risk-taking", and $s=M$ indicates "safe risk management" in the case of monitoring. We consider that choosing a safe risk management strategy $M$ means complying with international prudential rules. Banks in both countries are assumed to be risk-indifferent and have limited liability. If action $m$ is chosen, one unit of resources is invested in a portfolio that yields $r$ with probability $p_{m}$ and is zero otherwise. Opting for $M$ delivers a return $r$ with probability $p_{M}$, with $p_{M}>p_{m}$ but it also entails a monitoring cost equal to $c>0$ (with $r>c$ ). For the sake of simplicity, we assume that the action $M$ eliminates the credit risk, while the action $m$ does $\operatorname{not}^{8}$, that is $p_{m}=p$ and $p_{M}=1$. In the analysis that follows, we also assume that $p \in\left(\frac{1}{2}, 1\right)$.

Finally, we consider a deposit insurance scheme that is specific ${ }^{9}$ to each country, in which a fraction $\beta_{i}(i=h, f)$ of deposits, $0<\beta_{i}<1$, is refunded to depositors if a bank fails. Without loss of generality, we assume $\beta_{f}=1$ and let $\beta_{h}=\beta$. We suppose that implementing safe risk management is efficient ${ }^{10}$. This assumption implies that $1+r>c /(1-p)$.

TIMING The timing of the model is shown in the following figure.

\footnotetext{
${ }^{7}$ This assumption must not be interpreted in absolute terms but in comparison to the behavior of the emerging banking system.

${ }^{8}$ This assumption is not equivalent to perfect risk diversification because since risk-mitigation costs are incurred.

${ }^{9}$ For the sake of simplicity, we assume that the deposit insurance is funded by non-distorting taxation.

${ }^{10}$ In other words, the expected net gain induced by sound risk management $(1+r-c)$ exceeds the expected net gain induced by excessive risk-taking, $p(1+r)$
} 


\section{Figure 1: Timing of the model}

At date 0 , the banking sector in country $h$ chooses a strategy $s \in\{m, M\}$ and at date 1 , it states whether it is complying with international prudential standards (choice of $s=M$ ) or it makes no statement. Banks in developing countries often have substantial implementation costs for international regulatory standards and resist effective compliance (Walter, 2010) ${ }^{11}$. Financial systems in developing countries thus have low capacity to disclose relevant information to investors. We model this imperfect transparency by considering like Schultz (2004) that the investors are composed of informed and uninformed agents. Informed investors represent a fraction $\alpha(0 \leq \alpha \leq 1)$. They are endowed with sufficiently high expertise allowing them to exactly perceive the chosen risk strategy by the banking sector. The remaining fraction $\alpha(0 \leq \alpha \leq 1)$ are uninformed investors. For simplicity, we suppose that these agents can by no means observe the actual risk behavior ( $M$ or $m$ ) chosen by the home banking sector. This lack of observation can be due to their lack of expert knowledge. Indeed, they think that mock compliance occurs when the banking sector officially states compliance with international standards. Any missing information encourages the uninformed investors to be prudent and to assume the status quo in risk-taking even if the bank announces compliance. We also assume that these investors are so unsophisticated that they are unable to extract valuable information about risk-taking from interest rates. In the sequel, we use the parameter $\alpha$ as a proxy for the degree of financial transparency, and we assume that the fraction of informed investors increases with the degree of financial disclosure.

At date 2, the investors choose where to invest according to their knowledge about the risk strategy chosen by their home country's banking sector. At date 3, the banking sectors compete by setting the deposit rates offered to the investors. Finally at date 4 the depositors' investments materialize. It follows that investors learn the risk strategy chosen by their home country bank after having deposited their money.

INVESTORS Investors select the country that offers the highest expected return net of mobility costs. The expected utility of "informed" investors located at $x_{I}, x_{I} \in[0,1]$ and

\footnotetext{
${ }^{11}$ In developing countries, officially reporting compliance does not necessarily translate into facts and mock compliance (Walter, 2010) is very likely to occur. An additional complication is that real compliance is difficult for outside observers to assess (Walter, 2010). This difficulty follows from the lack of skilled accounting and auditing professionals and the high cost of implementing international accounting and disclosure standards (United Nations, 2008).
} 
who invest in their own country $h$ is given by

$$
U_{h}\left(x_{I}\right)=\left\{\begin{array}{lll}
p\left(1+r_{h}\right)+(1-p) \beta & \text { if } & s=m \\
1+r_{h} & \text { if } \quad s=M
\end{array}\right.
$$

If she invests in country $f$, her expected utility becomes

$$
U_{f}\left(x_{I}\right)=\left(1+r_{f}\right)-k\left(1-x_{I}\right)
$$

The expected utility of the uninformed investor located at $x_{U}, x_{U} \in[0,1]$ who invests in her own country $h$ is given by

$$
U_{h}\left(x_{U}\right)=p\left(1+r_{h}\right)+(1-p) \beta \quad \text { if } s \in\{m, M\}
$$

If she invests in country $f$, her expected utility becomes

$$
U_{f}\left(x_{U}\right)=\left(1+r_{f}\right)-k\left(1-x_{U}\right)
$$

If the bank in the emerging country chooses strategy $M$, the marginal informed and uninformed investors' locations respectively become

$$
\begin{aligned}
x_{I}^{M} & =\frac{r_{h}-r_{f}}{k}+1 \\
x_{U}^{M} & =\frac{p\left(1+r_{h}\right)-\left(1+r_{f}\right)+\beta(1-p)}{k}+1
\end{aligned}
$$

The market share $x^{M}$ of the bank in country $h$ if the prudent strategy is selected is obtained by calculating $x^{M}=\alpha x_{I}^{M}+(1-\alpha) x_{U}^{M}$ which yields

$$
x^{M}=\frac{\theta\left(1+r_{h}\right)-\left(1+r_{f}\right)+\beta(1-\theta)}{k}+1,
$$

where $\theta=\alpha+(1-\alpha) p$. If there is perfect transparency, all investors $(\alpha=1)$ are informed and if the bank chooses the safe strategy $M$ it follows that $\theta=1$. In case of perfect opacity, we have $\alpha=0$ and consequently $\theta=p$.

If there is no compliance reported by the jurisdiction $h$ or if there is mock compliance, the bank in the emerging country takes excessive risk. The informed and uninformed investors will choose the destination of their investment consistently, considering the strategy $m$ adopted by the domestic bank. The deposit supply faced by the bank in country $h$ equals

$$
x^{m}=\frac{p\left(1+r_{h}\right)-\left(1+r_{f}\right)+\beta(1-p)}{k}+1 .
$$




\subsection{Excessive risk-taking}

Each banking system selects the interest rate that maximizes its own profit taking the rival's rate as given.

$$
\begin{aligned}
& \underset{r_{h}}{\operatorname{Max}} \Pi_{h}^{m}=p x^{m}\left(r-r_{h}\right) \\
& \underset{r_{f}}{\operatorname{Max}} \Pi_{f}^{m}=\left(1-x^{m}\right)\left(r-r_{f}-c\right) .
\end{aligned}
$$

Solving the system of first order conditions yields the interest rates $r_{h}^{m}$ and $r_{f}^{m 12}$

$$
\begin{aligned}
& r_{h}^{m}=r-\frac{2 k-(1-p)(1+r-\beta)+c}{3 p} \\
& r_{f}^{m}=r-c-\frac{k+(1-p)(1+r-\beta)-c}{3}
\end{aligned}
$$

The corresponding market share of $h$ is

$$
x_{h}^{m}=\frac{2 k-(1-p)(1+r-\beta)+c}{3 k},
$$

Consequently, the market share for $f$ is $x_{f}^{m}=1-x_{h}^{m}$. Because sound risk management is efficient, we have $x_{h}^{m} \in(0,1)$ if and only if

$$
k>\bar{k}_{1}=\frac{(1-p)(1+r-\beta)-c}{2} .
$$

The profits of the banks in $h$ and $f$ can be written as

$$
\begin{aligned}
\Pi_{h}^{m} & =\left(x_{h}^{m}\right)^{2} k \\
\Pi_{f}^{m} & =\left(1-x_{h}^{m}\right)^{2} k
\end{aligned}
$$

\subsection{Sound risk management}

Under sound risk management, the market share of the bank in the emerging country is given by (1). Consequently, each bank selects the interest rate that maximizes its own profit by taking the rival's rate as given.

$$
\begin{aligned}
\underset{r_{h}}{\operatorname{Max}} \Pi_{h}^{M} & =x^{M}\left(r-r_{h}-c\right) \\
\underset{r_{f}}{\operatorname{Max}} \Pi_{f}^{M} & =\left(1-x^{M}\right)\left(r-r_{f}-c\right)
\end{aligned}
$$

\footnotetext{
${ }^{12}$ The offered interest rates $r_{i}^{m}(i=h, f)$ are positively signed for a sufficiently large $r$.
} 
After solving the system of best replies, we obtain the following interest rates ${ }^{13}$

$$
\begin{aligned}
& r_{h}^{M}=r-c-\frac{2 k-(1-\theta)(1+r-c-\beta)}{3 \theta} \\
& r_{f}^{M}=r-c-\frac{k+(1-\theta)(1+r-c-\beta)}{3}
\end{aligned}
$$

The corresponding market share of $h$ becomes

$$
x_{h}^{M}=\frac{2 k-(1-\theta)(1+r-\beta-c)}{3 k},
$$

which belongs to the interval $(0,1)$ if and only if $k>\bar{k}_{2}=\frac{(1-\theta)(1+r-c-\beta)}{2} .{ }^{14}$

The equilibrium profit functions are given by

$$
\begin{aligned}
\Pi_{h}^{M} & =\left(x_{h}^{M}\right)^{2} \frac{k}{\theta}, \\
\Pi_{f}^{M} & =\left(1-x_{h}^{M}\right)^{2} k .
\end{aligned}
$$

Notice that decreasing transparency $(\theta)$ increases the profit function $\Pi_{h}^{M}$. The reason for this increase is that lower transparency softens international bank competition and increases the captivity of the depositors.

\subsection{Choice of risk management strategy}

In this section, we study the incentives for the emerging country to comply with safe risk management. The emerging country chooses $M$ if the difference $\Pi_{h}^{M}-\Pi_{h}^{m}$ is positive. The following proposition may thus be stated.

Proposition 1. A cost threshold $\left(c^{*}>0\right)$ exists under which the banking system of country $h$ adopts safe risk management.

Proof (see Appendix 1.A.)

In other words, the sound strategy $M$ is chosen if the cost of monitoring is not too high, whereas the banking system opts for risk-taking $m$ if monitoring is too costly. It is important to note that the threshold value $c^{*}$ depends in turn on a set of parameters (see Appendix 1), which notably are $\beta, \theta$ and $k$. Consider, then, the limit case with no deposit insurance in

\footnotetext{
${ }^{13}$ As above, a sufficiently large $r$ guarantees that $r_{i}^{M}(i=h, f)$ are positive.

${ }^{14}$ The feasibility set of $k$ reduces to $k>\bar{k}=\max \left\{\bar{k}_{1}, \bar{k}_{2}\right\}$. Notice that $\bar{k}=\bar{k}_{1}$ if $1+r-\beta \in\left(\frac{c}{1-p}, \frac{\theta c}{\theta-p}\right)$ and $\bar{k}=\bar{k}_{2}$ if $(1+r-\beta) \in\left(\frac{\theta c}{\theta-p},+\infty\right)$ with $p \leq \theta<1$.
} 
the emerging country $(\beta=0)$ and fully disclosed financial information $(\theta=1)$. Then, it follows that the depositors are able to perfectly discipline the home banking system which adopts safe risk management.

It is easy to show that $\frac{\partial c^{*}}{\partial k}>0$ for any $\theta$, such as $\theta>p>1 / 2$. We can therefore state the following proposition.

Proposition 2. Increasing financial openness makes the banking system in the emerging country more prone to excessive risk-taking.

A higher degree of financial openness fuels banking competition and puts an upward pressure on the offered interest rates. Because we have $\left|\frac{\partial r_{h}^{m}}{\partial k}\right|>\left|\frac{\partial r_{h}^{M}}{\partial k}\right|$, the bank in the emerging country is encouraged to mitigate this stronger pressure by switching to a high risktaking strategy $(m)$. It also appears that increasing transparency mitigates this effect. This is in line with the theoretical literature regarding bank competition and risk-taking (Cordella and Yeyati, 2002).

Let us now investigate the influence of increased transparency (higher information disclosure) on the choice of sound risk management $(M)$.

Proposition 3. Given sufficient financial openness, higher disclosure makes the emerging banking system more likely to opt for sound risk management. In contrast, if capital mobility is low, higher disclosure decreases the likelihood of sound risk management.

\section{Proof (see Appendix 1.A.)}

To understand the intuition behind Proposition 3, we first totally differentiate the equality $\Pi_{h}^{M}\left(c^{*}, \theta\right)-\Pi_{h}^{m}\left(c^{*}\right)=0$ with respect to $\theta$ and $c^{*}$. It can be shown (see Appendix 1.B.) that $\frac{d c^{*}}{d \theta}$ has the same sign as $\frac{\partial \Pi_{h}^{M}}{\partial \theta}$. Analyzing this last term gives

$$
\frac{\partial \Pi_{h}^{M}}{\partial \theta}=\underbrace{\frac{2 S}{3 \theta} x_{h}^{M}(1+r-\beta-c)}_{+}+\underbrace{\left(x_{h}^{M}\right)^{2} \frac{-k S}{\theta^{2}}}_{-},
$$

Thus, increasing transparency has two opposite effects. On the one hand, banks have an incentive to behave more prudently because higher transparency increases their attractiveness to depositors. On the other hand, more transparency spurs bank competition ${ }^{15}$, which

\footnotetext{
${ }^{15}$ Increasing market transparency increases deposit supply elasticity and thus intensifies the competition perceived by the emerging country's bank. Indeed, it is easy to check that $\frac{\partial e_{h}}{\partial \theta}>0$ with $e_{h}=\frac{\partial x_{h}^{M}}{\partial r_{h}} \frac{r_{h}}{x_{h}^{M}}$. A similar argument is developed by Schultz (2004) .
} 
squeezes profit margins and thus leads to more bank risk-taking. Notice that the higher the mobility cost $k$, the stronger the profit squeeze will $\mathrm{be}^{16}$. Which effect ultimately dominates depends on the degree of financial openness. When the level of financial openness is high $\left(k<k^{*}\right)$, the profit squeeze created by higher transparency (increased $\theta$ ) is dominated by the attractiveness effect. However, when capital mobility is low $\left(k>k^{*}\right)$ the opposite occurs.

\section{Empirical Analysis}

\subsection{Estimated equation and data coverage}

In this section, we empirically test how bank risk-taking in emerging economies can be affected by disclosure (Discl) and financial openness (Kaopen), giving empirical support to our results from Propositions 2 and 3. For this purpose, we estimate the following model for a cross country sample of banks :

$$
\text { Risk }_{i k}=f\left(\text { Discl }_{i k}, \text { Kaopen }_{k}, X_{i k}, X_{k}\right),
$$

where subscripts $i$ and $k$ refer to bank and country respectively, while $X_{i k}$ and $X_{k}$ are vectors of control variables at the bank and country-level.

Our data set comprises 258 banks in 12 MENA countries (Algeria, Egypt, Israël, Jordan, Lebanon, Morocco, Oman, Qatar, Saudi Arabia, Syria, Tunisia, Turkey and United Arab Emirates) and in Turkey. The data used to calculate the bank-level variables are collected from the Bankscope dataset, over the 2005-2008 period. We distinguish between two subperiods, including and not including 2008, which is the first year of the recent financial crisis. All variables except Discl (2007) and Kaopen (2007) are averaged over the periods under study: 2005-2007 or 2005-2008. We cannot exploit the time-series dimension of our dataset because of the lack of variability in the disclosure and financial openness variables. We therefore conduct our analysis on a cross-sectional basis. Considering a short period could be viewed as an advantage. Indeed, if it happens that the banks that provide poor financial information are the most likely to exit from the sample, it is crucial to shorten the

\footnotetext{
${ }^{16}$ This relationship occurs because high profit margins (induced by a high mobility cost) imply larger losses if transparency increases.
} 
observed period as much as possible.

\subsection{Measuring disclosure}

We calculate a Bank Disclosure Index for each bank from the MENA Region, based on a framework originally proposed by Erlend Nier from the Bank of England (Baumann and Nier 2004), and later used by Huang (2006) and by Nier and Baumann (2006).

The Disclosure Index aggregates information originating from six categories, including: (1) Loans; (2) Other earning assets; (3) Deposits (4) Other funding; (5) Memo lines; and (6) Incomes. A sub-index is created for each category of disclosure. These sub-indices further contain a total of seventeen items, which are listed in Appendix 1. These items measure the level of detail provided by the banks regarding seventeen dimensions of accounting information in their published accounts and provided by the Bankscope database.

This index is used at the individual bank level. To give a picture of the situation in the MENA countries, we calculated a national index by averaging the index values of individual banks in a country, weighted or not by their assets (Figure 1). As expected, in Figure 1, we obtain a high level of disclosure for Jordan, Israel and some Gulf countries. The calculated index for the Turkish banking sector appears to be relatively high. This result is consistent with the decision taken by the Turkish authorities, in the wake of the massive banking crisis in 2001, to commit to regulation reforms by introducing a more severe control system augmented by stricter rules (Cimenoglu et al. 2009). In contrast, the Algerian and Syrian banking systems show very low disclosure indexes.

Figure 2: Disclosure Index (2007)

\subsection{Bank risk-taking variables}

We use three different measures for bank risk-taking, or, inversely, bank soundness.

These measures are calculated from bank balance sheet data provided by Bankscope: a liquidity index, a leverage ratio and a $z$-score. Although these variables are imperfect indicators of risk-taking, they are widely employed in the empirical literature. Moreover, in the light of the recent financial crisis, liquidity and leverage ratios are viewed as key indicators for bank risk-taking by reports of regulators. Regulators recommend that liquidity and leverage ratios 
should be introduced to supplement the existing regulatory parameters (FSA, 2009, BCBS 2009).

The liquidity ratio is measured by calculating liquid assets against to total assets. Generally, banks with higher ratios are perceived as being safer because of the risk-mitigating character of liquid assets, which allow the bank to meet unexpected withdrawals. DemirgücKunt and Huizinga (2004, p. 383) consider liquidity to be one of the most reliable accounting measures of bank risk, in particular for the developing countries. Equity and profit ratios are more subject to accounting manipulation and tend to be overstated at weaker banks.

The leverage indicator is expressed as the ratio of total assets to total book equity capital. Banks typically increase their risk-taking by borrowing to acquire more assets, with the goal of raising their return on equity. According to the Turner Report (FSA, 2009, p. 67), using this leverage ratio in addition to liquidity is very important. Indeed, the crisis revealed that assets that are believed to be of a low risk type can become highly illiquid and risky when systemic problems emerge.

The z-score represents a universal measure of soundness in banking-related studies. This index inversely proxies the probability of banks' failure. The merit of this index is that it combines profitability, solvability and volatility in a relatively simple measure that is based solely on accounting information. This index is defined as:

$Z_{i}=\frac{R O A_{i}+E / T A_{i}}{\sigma R O A_{i}}$, where $R O A_{i}$ is the period-average return on assets for bank $i, E / T A_{i}$ stands for the period average equity to total assets, and $\sigma R O A_{i}$ represents the standard deviation of $R O A$ that captures the volatility of returns. The z-score increases with higher profitability and capitalization levels and decreases with higher return volatility. Larger values for the z-score imply lower risk-taking and, thus, greater bank soundness.

\subsection{Financial openness and control variables}

To measure financial openness, which is a key variable of our theoretical model, only countrylevel variables are available. We use the Kaopen index which is widely used in financial integration studies. This proxy for openness in capital transactions, developed by Chin and Ito $(2002,2006)$ aims to measure the extent of capital controls based on the information from the IMF's Annual Report on Exchange Arrangements and Exchange Restrictions (AREAER).

The Kaopen index is based on binary variables that indicate restrictions on current ac- 
count and capital account transactions. The index also takes into account the presence of multiple exchange rates and the requirement for the surrender of export proceeds. This index takes on higher values when the country is more open to cross-border capital transactions. A new statistical series for the Kaopen index is provided by Chinn and Ito (2007) for 182 countries, updated until 2007.

To isolate the impact of disclosure and financial openness on bank risk-taking (or soundness), we use a number of bank-level and country-level control variables. Empirical literature on bank risk-taking always controls for bank size, which is proxied by the natural logarithm of total assets. As noted by Gonzalez (2005), the effect of the bank size is not easy to forecast because under a "too big to fail" behavior, larger banks can have a greater incentives to take risks than smaller banks. However, larger banks also have a greater potential to diversify and reduce their risk-taking attitude. As a complement to the bank size, we use the variable "share" defined as the contribution of each bank to the total assets in the banking sector of each country. Following Berger et al. (2009), we control for the asset composition of banks.

The indicators are the share of total loans in total assets and the ratio of fixed assets to total assets. These indicators control for the difference in the structure of bank business. Traditionally, the public ownership of a bank is captured by a dummy variable that is set to 1 when government's ownership exceeds $50 \%$.

To take into account the macroeconomic environment at the country-level, we control for the degree of economic development using the real GDP per capita, the real GDP growth and the inflation rate. Finally, in the MENA region, some economies are strongly resource-based (oil and gas exporters). For this reason, we introduce the dummy variable "res" that takes the value 1 for oil or gas exporters. The bank and country-level variables that are used in our empirical analysis are summarized in Table 1. The descriptive statistics for bank-level variables and the correlations among variables are shown in Appendix 2.

\section{Table 1: Variables definitions and data sources}

\subsection{Results}

Table 2 presents the results for our main regressions. All of the results are estimated using OLS, and standard errors are adjusted by the White method because of heteroskedasticity. 
In these equations, we regress risk-taking indicators (leverage) or soundness indicators (Liquidity and z-score) against financial openness, disclosure and control variables.

In a nutshell, these regressions yield significant results with signs that are consistent with our theoretical model. We obtain more precise coefficients for the liquidity and leverage equations than for the z-score.

In columns (1) and (3), the dependent variables are measured over the 2005-2007 period. In columns (2) and (4) we repeat the same estimation by including 2008, which is the first year of the recent financial crisis. It appears that in both estimations the results are very close.

In line with Proposition 2, we find that the financial openness proxy (KAOPEN) affects liquidity (the soundness indicator) negatively and leverage (the risk indicator) positively. The financial openness variable is not significant in the $\mathrm{z}$-score regression.

There is clear evidence that the disclosure index (in $\log$ ) influences the liquidity and z-score positively, and leverage negatively. These very significant results in all of our regressions are consistent with Proposition 3, according to which more disclosure increases the likeliness that the banking system opts for sound risk management in the case of sufficient financial openness.

Regarding the bank specific control variables, we find that a larger bank size (log of total bank assets) is associated with relatively higher risk-taking and lower soundness. This evidence confirms the results obtained by the empirical literature on bank risk-taking. However, the banks'share in the total assets of their home (banking) sector is significant and negative only in the liquidity regression. The bank soundness, measured by liquidity, appears to be affected by the structure of their balance sheet (share of total loans in total assets). Berger et al. (2009) recently obtained a similar relationship.

Among the country-level characteristics, the dummy variable RES (oil and gas exporters) is significant in explaining bank soundness and bank risk-taking, which are respectively captured by liquidity and leverage, respectively. The annual GDP growth affects liquidity positively and leverage negatively. In addition, we find that a higher per capita GDP is only consistent with lower liquidity.

\section{Table 2: OLS Regressions}

To check for robustness, we next test whether the previous results change with the other 
specifications. Our regressions might not account for all of the country aspects of the bank environment. Indeed, the explanatory power of bank level variables, such as the disclosure indicator we use, could come from country specific differences (Nier and Baumann, 2006). To check whether we control for all differences across countries, we replace the country variables with dummies. The introduction of country fixed effects (Table A4 in Appendix 2) confirms our initial results, in particular for liquidity and leverage indicators, but makes the impact of disclosure on the z-score index less significant.

As a second robustness test, we once again estimate all of our specifications by successively excluding one country after the other. In Table A5 in Appendix 2 we highlight the regressions for which the variable "Diclosure" (DISCL) exhibits the largest standard error. In other words, we report the worst of the fourteen tested equations for each specification. In every case, the exclusion of Turkey, which contains the largest number of banks in our sample, slightly weakens the significance of the disclosure effect.

These tests show that our results are particularly robust especially concerning the liquidity ratio and the leverage indicator, but to a lesser extend. After controlling for robustness, the disclosure indicator still remains a significant determinant of banks' soundness. We, however, observe the fragility of our z-score regression, which is not a very surprising result given the lack of temporal data.

Potential endogeneity problems can affect the measured impact of disclosure on risktaking variables. For example, a bank's decision to disclose limited information could be explained by the desire to hide high risk-taking behavior. More precisely, an inverse causality between risk-taking and disclosure could be suspected. Nier and Baumann (2006, p. $344)$ consider that the endogeneity bias for disclosure variables is less plausible in a crosssectional setup. Nevertheless, we address this potential problem with instrumental variables estimations (Two stages least squares) that are adapted to the existence of heteroskedasticity. The choice of instruments is, however, relatively limited in a cross-sectional analysis. We tested many bank level variables, including public ownership and foreign ownership, and country level governance variables, which can be correlated with our disclosure variable. The only significant instrument that we found is public ownership. In the literature of corporate governance as applied to banks in developing countries there is evidence for a positive relationship between the public ownership status and disclosure. For instance, Arun and Turner (2004, p. 374) consider that one reason for government ownership is the severe information problems inherent in developing financial systems. Using only one instrument, however, 
does not allow the validity of instruments to be asserted through an overidentification test. Nevertheless, public ownership does not appear to be significant in the econometric works analyzing the bank risk-taking (Angkinand and Wihlborg 2010, Berger et al 2009, Gonzales 2005, Barth et al 2004). In all of our IV regressions, we use the Stock and Yogo test to verify that there is no concern regarding weak instruments. We show that the Cragg-Donald and Kleibergen-Paap F-statistics are above 10 and exceed the tabulated value.

\section{Table 3: Instrumental Variables Regressions (2SLS)}

\section{Conclusion}

The aim of this paper is to analyze how international competition for deposits and information disclosure affects banks' risk-taking behavior in emerging countries. The model we develop is also tested econometrically using data on MENA countries.

Briefly, we build a model that examines the levels of financial openness and disclosure of information and indicates for which of these levels implementing international regulatory standards in developing and emerging countries is a winning strategy. One of our main results is that increasing financial openness also increases the likelihood of the emerging banking center's compliance with safe risk management. It appears that the effect of information disclosure on risk-taking is ambiguous. On the one hand, greater financial transparency increases the attractiveness of deposits and motivates banks to behave more prudently. On the other hand, greater disclosure spurs bank competition and squeezes profit margins. The first effect outweighs the second effect only if the level of financial openness is sufficiently high. From a policy analysis viewpoint, this result implies that promoting successful financial disclosure in an emerging country requires sufficient financial openness.

Our empirical analysis is based on a disclosure index computed at the bank level. After controlling for bank- and country-level characteristics, we test the impact of financial openness and disclosure on several risk-taking variables. The risk indicators were chosen for their relevance during the recent financial crisis. The MENA region plus Turkey is not perfectly homogenous, but many of these economies can be considered emerging and are characterized by massive capital flight. The regressions yield results that are consistent with our theoretical propositions. We find a significant negative relationship between the proxy 
for financial openness and the risk-taking indicators. There is also clear evidence that disclosure positively impacts the soundness indicators. Finally, instrumental variable regressions confirm these results. 


\section{Appendix 1: The model}

\subsubsection{Appendix 1.A. Proof of Propositions}

Proof of Proposition 1: The threshold-value $c^{*}=\frac{2 k-(1-\theta)(1+r-\beta)-\sqrt{\theta}(2 k-(1-p)(1+r-\beta))}{(\theta+\sqrt{\theta}-1)}$ is derived from the equality $k S\left[\left(\frac{x_{h}^{M}}{\theta}\right)^{2}-\left(x_{h}^{m}\right)^{2}\right]=0$. It follows that $c^{*}>0$ if $k>$ $\max \{\bar{k}, \tilde{k}\}$, where $\tilde{k}=\frac{(1+r-\beta)((1-\theta)-(1-p) \sqrt{\theta})}{2(1-\sqrt{\theta})}$. Notice that $\tilde{k}$ is strictly positive if $\theta \geq$ $p>\frac{(\theta+\sqrt{\theta}-1)}{\sqrt{\theta}}$. If $\theta \geq \frac{(\theta+\sqrt{\theta}-1)}{\sqrt{\theta}}>p$ holds, we have $\tilde{k}<0$. In this case it follows that for any value of the net return $1+r-\beta$ we get $c^{*}>0$.

Proof of Proposition 3: Calculating the derivative of the threshold $\cos t c^{*}$ with respect to $\theta$ and with respect to $\pi$ yields $\frac{\partial c^{*}}{\partial \theta}>0$ if $\max \{\bar{k}, \tilde{k}\}<k<k^{*}$. Since we assume that $p \in\left(\frac{1}{2}, 1\right)$, it is easy to check that $k^{*}>\max \left\{\bar{k}_{1}, \bar{k}_{2}\right\}$ and $k^{*}>\tilde{k}$. And $\frac{\partial c^{*}}{\partial \theta}<0$ if $k>k^{*}$ with $k^{*}=\frac{p(1+\theta)(1+r-\beta)}{2(2 \sqrt{\theta}-\theta)}$. We can thus state the following proposition.

\subsubsection{Appendix 1.B.}

After having totally differentiated the equality $\Pi_{h}^{M}\left(c^{*}, \theta\right)-\Pi_{h}^{m}\left(c^{*}\right)=0$ with respect to $\theta$ and $c^{*}$, we obtain $\frac{d c^{*}}{d \theta}=\frac{\frac{\partial \Pi_{h}^{M}}{\partial \theta}}{\frac{\partial \Pi_{h}^{m}}{\partial c^{*}}-\frac{\partial \Pi_{h}^{M}}{\partial c^{*}}}$. Using the explicit values of $\Pi_{h}^{m}$ and $\Pi_{h}^{M}$, it is easy to show that $\frac{\partial \Pi_{h}^{m}}{\partial c^{*}}-\frac{\partial \Pi_{h}^{M}}{\partial c^{*}}=\frac{2 S}{3}\left(x_{h}^{m}-x_{h}^{M} \frac{(1-\theta)}{\theta}\right)$. The equality $\Pi_{h}^{M}\left(c^{*}, \theta\right)=\Pi_{h}^{m}\left(c^{*}\right)$ implies $x_{h}^{M}\left(c^{*}\right) \frac{1}{\sqrt{\theta}}=x_{h}^{m}\left(c^{*}\right)$. Since $p \leq \theta \leq 1$ and $p \in\left(\frac{1}{2}, 1\right)$, we deduce that $x_{h}^{m} \geq x_{h}^{M}$ at $c^{*}$. It follows that $\frac{\partial \Pi_{h}^{m}}{\partial c^{*}}-\frac{\partial \Pi_{h}^{M}}{\partial c^{*}}>0$ for all $\theta \in[p, 1]$ and consequently $\frac{d c^{*}}{d \theta}$ has the same sign as $\frac{\partial \Pi_{h}^{M}}{\partial \theta}$.

\section{Appendix 2: Empirical analysis}

The bank disclosure indexes measure the level of detail that banks provide on seventeen dimensions of accounting information in their published accounts and provided by Bankscope database (Method of Baumann and Nier 2004). For all indexes, zero was assigned if there 
was no entry in any of the corresponding categories and 1 otherwise, except for the index for securities by "type" and the "capital" index. For the "securities by type" item, a 0 was assigned if there was no entry for any of the associated disclosure categories, a 1 if there was only an entry for the coarse breakdown and a 2 if there was an entry for the detailed breakdown. For the "capital" item, a 0 was assigned if there was no entry in any of the categories, a 1 if there was one entry only, a 2 if there were two entries and a 3 if there were three or four entries. Aggregating the information scores on the 17 disclosure items, the composite index can be created with the following formula: Discl $=\frac{1}{21} \sum_{i=1}^{17} s_{i}$

\section{Subindex Categories:}

\section{Loans:}

S1: Loans by maturity: Less than three months, three to six months, six months to one year, one to five years, more than five years

S2: Loans by type: Loans to municipalities/government, mortgages, HP/lease, other loans

S3: Loans by counterpart: Loans to group companies, loans to other corporates, loans to banks

S4: Problem loans: Total problem loans

S5: Problem loans by type: Overdue/restructured/other nonperforming

\section{Other earning assets:}

S6: Securities by type: Detailed breakdown: Treasury bills, other bills, bonds, CDs, equity investments, other investments Coarse breakdown: government securities, other listed securities, non listed securities

S7: Securities by holding purpose:Investment securities, trading securities

\section{Liabilities Deposits:}

S8: Deposits by maturity: Demand, savings, less than three months, three to six months, six months to one year, one to five years, more than five years

S9: Deposits by type of customer: Bank deposits, municipal/government

\section{Other funding:}

S10: Money market funding: Total money market funding 
S11: Long-term funding: Convertible bonds, mortgage bonds, other bonds, subordinated debt, hybrid capital

\section{Memo lines:}

S12: Reserves: Loan loss reserves (memo)

S13: Capital: Total capital ratio, tier 1 ratio, total capital, tier 1 capital

S14: Contingent liabilities: Total contingent liabilities

S15: Off-balance-sheet items: Off-balance-sheet items

\section{Income statement:}

S16: Non interest income: Net commission income, net fee income, net trading income S17: Loan loss provisions: Loan loss provisions 
Table A1: Summary Statistics

Table A2: Number of banks included in the sample

Table A3: Correlation matrix of main explanatory variables

Table A4: OLS regressions with country dummies

Table A5: OLS regressions dropping countries one by one 


\section{References}

1. Admati A. R. and Pfleiderer P. (2000), Forcing firms to talk: Financial disclosure regulation and externalities, Review of Financial Studies 13, 479-519.

2. Allen F. and Gale D. (1999), Optimal Financial Crises, Journal of Finance 53, 1245 1284.

3. Almounsor A. (2008), Capital Flight Accounting and Welfare Implications in the MENA Region, Review of Middle East Economics and Finance, Vol. 4, Iss.2.

4. Angkinand A., Wihlborg C. (2010), Deposit Insurance Coverage, Ownership, and Banks' Risk-Taking in Emerging Markets, Journal of International Money and Finance, Vol. 29, p. 252-274.

5. Anzoategui D., Martinez-Peria M.S. and Rocha R. (2010), Bank Competition in the Middle East and Northern Africa Region, Policy Researh Working Paper 5363, World Bank, July.

6. Arun T.G., Turner J.D. (2004), Corporate Governance of Banks in Developing Economies: concepts and issues, Corporate Governance: An International Review, Vol. 12 (3), p. 361-370.

7. Balin B. J. (2008), Basel I, Basel II, and Emerging Markets: A Nontechnical Analysis, The Johns Hopkins University School of Advanced International Studies (SAIS).

8. Baumann U. and Nier E. (2004), Disclosure, Volatility, and Transparency: An Empirical Investigation into the Value of Bank Disclosure, FRBNY Economic Policy Review, sept., p. 31-45.

9. Barajas A., Steiner R. (2000), Depositor Behavior and Market Discipline in Colombia. IMF Working Paper, 214. December. BIS (2006), The Banking System in Emerging Economies: How Much Progress has been made? Monetary and Economic Department BIS Papers No 28.

10. Barth J. R., Caprio G. J., Levine R. (2004), Bank regulation and supervision: what works best? Journal of Financial Intermediation 13, p. 205-248. 
11. Basel Committee on Banking Supervision (2009), International Framwork for Liquidity Risk Measurement, Standards and Monitoring”, Consultative document, BIS, Basel, Dec.

12. Bhattacharya, S., Boot A.,Thakor, A., (1998), The Economics of Bank Regulation, Journal of Money Credit and Banking, 30(4), S.745-770.

13. Berger A.N., Klapper L.F., Turk-Ariss R. (2009), Bank Competition and Financial Stability, Journal of Financial Services Research 35, 99-118.

14. Boot A. W. A. and Thakor A., V. (2001) The many faces of information disclosure, Review of Financial Studies, 14, 1021-1057.

15. Calomiris C. W. and Kahn C. (1991), The role of demandable debt in structuring optimal banking arrangements, American Economic Review 81, 497-513.

16. Calomiris C.W., Powell A. (2001), Can Emerging Market Bank Regulators Establish Credible Discipline: The Case of Argentina, 1992-99, in Mishkin F. (ed), Prudential Supervision: What Works and What Doesn't, NBER Conference Report series. Chicago and London: University of Chicago Press, 147-96.

17. Chen Y., Banking Panics: The Role of the First-Come, First Served Rule and Information Externalities, Journal of Political Economy, 107, 946-968.

18. Chiesa G. (2001), Incentive-Based Lending Capacity, Competition and Regulation in Banking, Journal of Financial Intermediation 10, 28-53.

19. Chinn M.D., Hito H.(2006), What matters for financial development? Capital controls, institutions, and interactions, Journal of Development Economics 81 (2006) 163- 192.

20. Chinn M.D., Hito H. (2008), A New Measure of Financial Openness, Journal of Comparative Policy Analysis 10(3), pp.307-320.

21. Cigogna A. (2009), Chap. "North Africa", in Bongini P., Chiarlone S. and Ferri G. (2009), Emerging Banking Systems, Palgrave Macmillan, 126-161.

22. Cimenoglu A., Ferrazzi M. and Revoltella D. (2009), Chap. "Turkey", in Bongini P., Chiarlone S. and Ferri G. (2009), Emerging Banking Systems, Palgrave Macmillan, 183-204. 
23. Collier P., Hoeffler A. and Pattillo C. (1999), Flight Capital as a Portfolio Choice, World Bank Policy Research Working Paper No. 2066 and IMF Working Paper 99/171.

24. Cordella T. and Yeyati E.L. (2002), Financial opening, deposit insurance, and risk in a model of banking competition, European Economics Review, 46, 471-485.

25. Creane S., Goyal R., Mobarak A.M., Sab R. (2007), Measuring Financial Developement in the Middle East and North Africa: A New Database, Vol.53, IMF Staff Paper, Iss. 3., 479-511.

26. Demirgüc-Kunt A., Huizinga H. (2004), Market Discipline and Deposit Insurance, Journal of Monetary Economics, 51, 375-399.

27. Demirgüç-Kunt A., Detragiache E.,Tressel T. (2008), Banking on the principles: Compliance with Basel Core Principles and Bank Soundness, Journal of Financial Intermediation $17,511-542$.

28. FSA, Financial Services Authority (2009), The Turner Review. A regulatory response to the global banking crisis, March, London.

29. FSI-BIS (2008), 2008 FSI (Financial Stability Institute) Survey on the Implementation of the New Capital Adequacy Framework in non-Basel Committee Member Countries, August.

30. Gonzalez F. (2005), Bank regulation and risk-taking incentives: An international comparison of bank risk, Journal of Banking \& Finance, 29, 1153-1184.

31. Hellwig M., (2005), Market Discipline, Information Processing, and Corporate Governance, Working Paper Series of the Max Planck Institute for Research on Collective Goods 9, Max Planck Institute for Research on Collective Goods.

32. Huang R., (2006), Bank Disclosure Index. Global Assesment of Bank Disclosure Pratices, World Bank, sept.

33. Hyytinen A. and Takalo T., (2002), Enhancing Bank Transparency: A Re-assessment, European Finance Review, 429-445.

34. Llewellyn D. T. (2003), Some Lessons for Bank Regulation from Recent Financial Crises, in : Mullineux A.W., Murinde V. (eds.) Handbook of International Banking, Edward Elgar Publishing, 428-85. 
35. Loungani P. and Mauro P. (2000), Capital Flight from Russia, in Masson P., Gotur P., and Lane T., International Economic Policy Review, IMF, Vol 2., 141-156.

36. Martinez-Peria M.S., Schmukler S.L. (2001), Do Depositors punish Banks for Bad Behavior? Market Discipline Deposit Insurance and Banking Crises. Journal of Finance, 56(3), 1029-1051.

37. Nier E., Baumann U. (2006), Market Discipline, Disclosure and Moral Hazard in Banking, Journal of Financial Intermediation, 15, 332-361.

38. Onder Z., Ozyildirim S. (2008), Market Reaction to Risky Banks: Did Generous Deposit Guarantee Change It? World Development, August, Vol. 36, iss. 8, 1415-35.

39. Perotti E. (2002), Lessons from the Russian Meltdown: The Economics of soft Legal Constraints, International Finance, 5:3, 359-399.

40. Powell A. (2002), A capital Accord for Emerging Economies?, World Bank Policy Research Working Paper 2808, March.

41. Prasad E., Rogoff K., Wei S-J., and Kose M. A. (2003), Effects of Financial Globalization on Developing Countries: Some Empirical Evidence, IMF Occasional Paper 220 (Washington, International Monetary Fund).

42. Prasad E., Rajan R.G., and Subramanian A., (2006), Patterns of International Capital Flows and Their Implications for Economic Development, in The New Economic Geography: Effects and Policy Implications (Kansas City, Missouri, Federal Reserve Bank of Kansas City).

43. Schultz Ch. (2004), Market Transparency and Product Differentiation, Economics Letters, May 2004, V. 83, iss. 2, 173-78.

44. Turk-Ariss R. (2009), Competitive Behavior in Middle East and North Africa Banking Systems, The Quarterly Review of Economics and Finance, 49, 693-710.

45. Ungan E., Caner S., Ozyildirim S. (2008) Depositors' Assessment of Bank Riskiness in the Russian Federation, Journal of Financial Services Research, April, Vol.33, Iss. $2,77-100$.

46. Vives X. (2006), Banking and Regulation in Emerging Markets: The Role of External Discipline. World Bank Research Observer, Vol. 21, Iss. 2, 176-206. 
47. Walter, A. (2010) Adopting international financial standards: convergence or divergence in the global political economy? In: Underhill, Geoffrey R. D. and Blom J. and Mügge D., (eds.) Global financial integration thirty years on: from reform to crisis. Cambridge University Press.

48. United Nations, (2008), Practical Implementation of International Financial Reporting Standards: Lessons Learned, New York: United Nations. 
Figure 1: Timing of the model

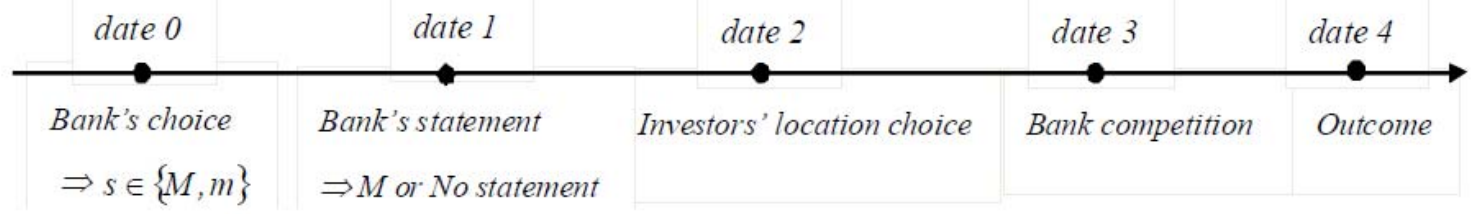

Figure 2: Disclosure index

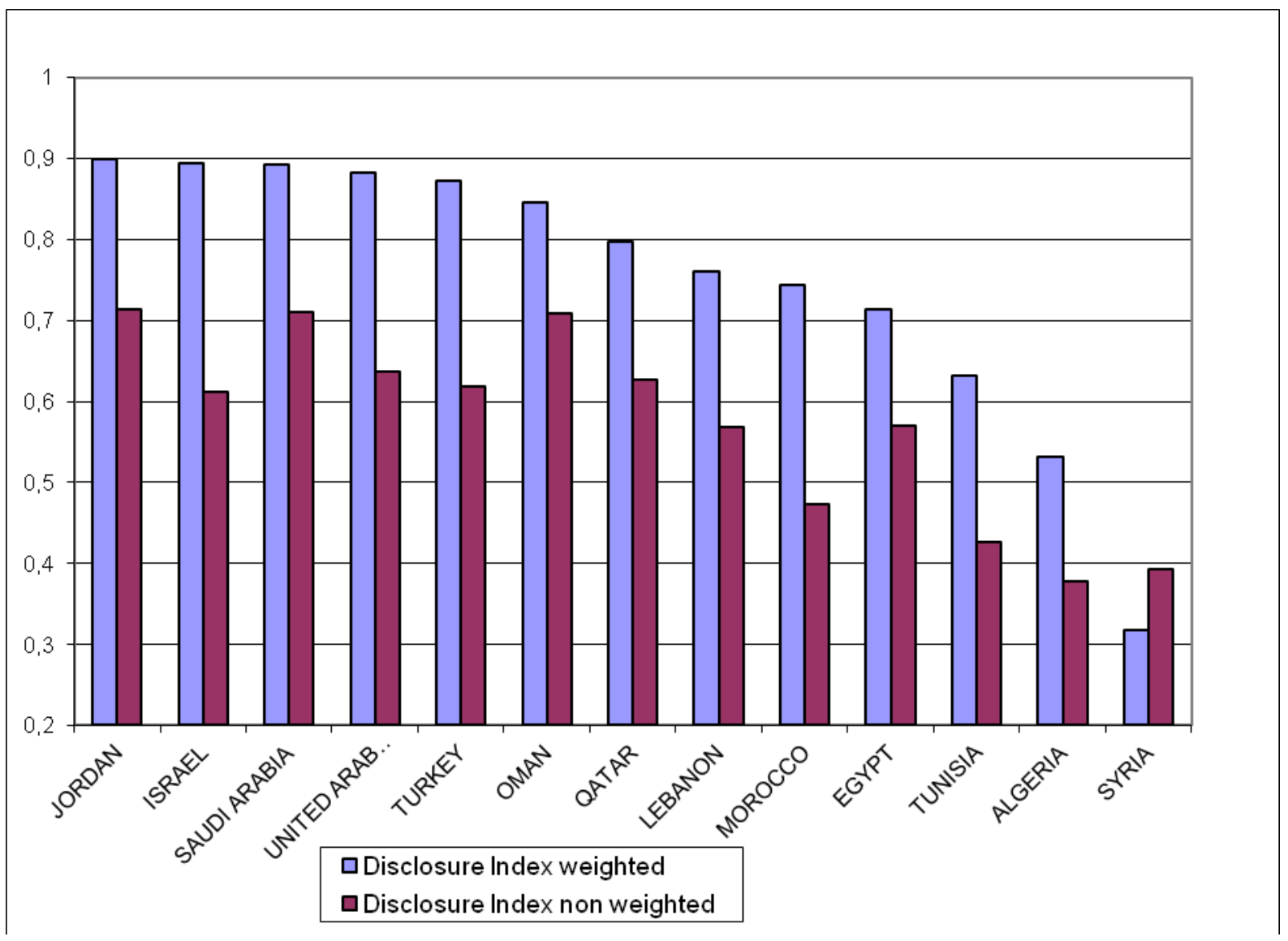


Table 1: Variables definitions and data sources

\begin{tabular}{|c|c|c|}
\hline Variable & Description & Source \\
\hline LIQUID_TA & $\begin{array}{l}\text { Liquid asset to total asset; values averaged over 2005-2007 and } \\
\text { 2005-2008 }\end{array}$ & Bankscope \\
\hline LEVERAGE & $\begin{array}{l}\text { Ratio of total assets to total book equity capital, average over 2005- } \\
2007 \text { and 2005-2008. }\end{array}$ & Bankscope \\
\hline Z-SCORE & $\begin{array}{l}\text { Average return on assets (ROA) plus equity-asset ratio, divided by } \\
\text { the standard deviation of ROA. To calculate } \sigma_{\mathrm{ROA}} \text {, we use data from } \\
\text { the six previous years }(2003-2008)\end{array}$ & Bankscope \\
\hline DISCL & $\begin{array}{l}\text { Disclosure index, as defined by Baumann and Nier 2004, see } \\
\text { description in main text, year } 2007\end{array}$ & Bankscope \\
\hline KAOPEN & $\begin{array}{l}\text { Proxy of openness degree in capital account transactions developed } \\
\text { by Chinn and Ito (2002 and 2006), year } 2007 .\end{array}$ & $\begin{array}{l}\text { Chinn and Ito } \\
\text { (2007) }\end{array}$ \\
\hline SIZE & $\begin{array}{l}\text { Natural logarithm of value of bank total assets, average over 2005- } \\
2007 .\end{array}$ & Bankscope \\
\hline SHARE & $\begin{array}{l}\text { Contribution of each bank to the total assets in the banking sector of } \\
\text { each country, average over 2005-2007 }\end{array}$ & Bankscope \\
\hline LOANS & Loans to total assets ratio, average over 2005-2007 & Bankscope \\
\hline FIXEDASSET & Fixed assets to total assets ratio, average over 2005-2007 & Bankscope \\
\hline PUBLIC & $\begin{array}{l}\text { Dummy variable that takes the value } 1 \text { when government exceed } \\
50 \% \text { of total bank ownership and takes } 0 \text { otherwise. }\end{array}$ & Bankscope \\
\hline GDPCAP & GDP per capital of each country, average over 2005-2007. & WB \\
\hline GDPGR0507 & GDP growth rate of each country, average over 2005-2007. & WB \\
\hline GDPGR0007 & GDP growth rate of each country, average over 2000-2007. & WB \\
\hline INFLATION & Inflation rate of each country, average over 2005-2007. & WB \\
\hline RES & $\begin{array}{l}\text { Dummy variable that takes the value } 1 \text { for oil or gas exporter } \\
\text { country. }\end{array}$ & \\
\hline
\end{tabular}


Table 2: OLS Regressions

\begin{tabular}{|c|c|c|c|c|c|}
\hline VARIABLES & $\begin{array}{c}(1) \\
\text { LIQUID_TA }\end{array}$ & $\begin{array}{c}(2) \\
\text { LIQUID_TA0508 }\end{array}$ & $\begin{array}{c}\text { (3) } \\
\text { LEVERAGE }\end{array}$ & $\begin{array}{c}(4) \\
\text { LEVERAGE0508 }\end{array}$ & $\begin{array}{c}\text { (5) } \\
\text { Z-SCORE }\end{array}$ \\
\hline DISCL & $\begin{array}{c}0.0705 * * * \\
(0.0237)\end{array}$ & $\begin{array}{c}0.0624 * * * \\
(0.0236)\end{array}$ & $\begin{array}{c}-2.945^{* *} \\
(1.360)\end{array}$ & $\begin{array}{c}-3.101 * * \\
(1.296)\end{array}$ & $\begin{array}{c}0.352 * * \\
(0.156)\end{array}$ \\
\hline KAOPEN & $\begin{array}{c}-0.00877^{* *} \\
(0.00432)\end{array}$ & $\begin{array}{l}-0.00819 * \\
(0.00430)\end{array}$ & $\begin{array}{c}0.772 * * * \\
(0.210)\end{array}$ & $\begin{array}{c}0.699 * * * \\
(0.203)\end{array}$ & $\begin{array}{c}0.0295 \\
(0.0308)\end{array}$ \\
\hline SIZE & $\begin{array}{c}-0.0474 * * * \\
(0.00673)\end{array}$ & $\begin{array}{c}-0.0439 * * * \\
(0.00623)\end{array}$ & $\begin{array}{c}0.920 * * * \\
(0.324)\end{array}$ & $\begin{array}{c}1.004 * * * \\
(0.317)\end{array}$ & $\begin{array}{l}2.911 \\
(2.618)\end{array}$ \\
\hline SHARE & $\begin{array}{c}0.462 * * * \\
(0.0955)\end{array}$ & $\begin{array}{c}0.449 * * * \\
(0.0897)\end{array}$ & $\begin{array}{c}9.772 \\
(7.110)\end{array}$ & $\begin{array}{c}7.699 \\
(6.875)\end{array}$ & $\begin{array}{l}1.360 * * \\
(0.672)\end{array}$ \\
\hline LOANS & $\begin{array}{c}-0.666^{* * *} \\
(0.0445)\end{array}$ & $\begin{array}{l}-0.626^{* * *} \\
(0.0458)\end{array}$ & $\begin{array}{l}1.096 \\
(2.096)\end{array}$ & $\begin{array}{c}0.681 \\
(1.935)\end{array}$ & $\begin{array}{l}-2.802 \\
(2.567)\end{array}$ \\
\hline GDPGR0507 & $\begin{array}{l}0.0159 * * * \\
(0.00526)\end{array}$ & $\begin{array}{l}0.0153^{* * *} \\
(0.00518)\end{array}$ & & & \\
\hline RESS & $\begin{array}{c}0.0491 * * \\
(0.0210)\end{array}$ & $\begin{array}{c}0.0497 * * \\
(0.0214)\end{array}$ & $\begin{array}{c}-4.284^{* * *} \\
(1.371)\end{array}$ & $\begin{array}{c}-3.506 * * \\
(1.393)\end{array}$ & $\begin{array}{l}0.0760 \\
(0.126)\end{array}$ \\
\hline GDPCAP & $\begin{array}{c}-1.45 \mathrm{e}-06^{* *} \\
(7.22 \mathrm{e}-07)\end{array}$ & $\begin{array}{c}-1.81 \mathrm{e}-06 * * * \\
(6.97 \mathrm{e}-07)\end{array}$ & $\begin{array}{c}3.01 \mathrm{e}-05 \\
(4.49 \mathrm{e}-05)\end{array}$ & $\begin{array}{c}2.09 \mathrm{e}-05 \\
(4.29 \mathrm{e}-05)\end{array}$ & $\begin{array}{l}-1.65 \mathrm{e}-06 \\
(5.01 \mathrm{e}-06)\end{array}$ \\
\hline GDPGR0007 & & & $\begin{array}{c}-1.621^{* * *} \\
(0.363)\end{array}$ & $\begin{array}{c}-1.566 * * * \\
(0.337)\end{array}$ & $\begin{array}{c}0.0581 \\
(0.0417)\end{array}$ \\
\hline Constant & $\begin{array}{l}0.917 * * * \\
(0.0877)\end{array}$ & $\begin{array}{c}0.878 * * * \\
(0.0890)\end{array}$ & $\begin{array}{c}16.22^{* * *} \\
(5.004)\end{array}$ & $\begin{array}{c}15.72 * * * \\
(4.910)\end{array}$ & $\begin{array}{l}-0.551 \\
(0.681)\end{array}$ \\
\hline $\begin{array}{l}\text { Observations } \\
\text { R-squared }\end{array}$ & $\begin{array}{c}238 \\
0.700\end{array}$ & $\begin{array}{c}238 \\
0.691\end{array}$ & $\begin{array}{c}205 \\
0.369\end{array}$ & $\begin{array}{c}207 \\
0.358\end{array}$ & $\begin{array}{c}166 \\
0.131\end{array}$ \\
\hline
\end{tabular}

Heteroskedasticity consistent standard errors in parentheses *** $\mathrm{p}<0.01,{ }^{* *} \mathrm{p}<0.05,{ }^{*} \mathrm{p}<0.1$ 
Table 3: Instrumental Variables Regressions (2SLS)

\begin{tabular}{|c|c|c|c|c|c|}
\hline VARIABLES & $\begin{array}{c}(1) \\
\text { LIQUID_TA }\end{array}$ & $\begin{array}{c}(2) \\
\text { LIQUID_TA0508 }\end{array}$ & $\begin{array}{c}\text { (3) } \\
\text { LEVERAGE }\end{array}$ & $\begin{array}{c}(4) \\
\text { LEVERAGE0508 }\end{array}$ & $\begin{array}{c}\text { (5) } \\
\text { Z-SCORE }\end{array}$ \\
\hline LNDISCL & $\begin{array}{l}0.198^{*} \\
(0.105)\end{array}$ & $\begin{array}{c}0.114 \\
(0.0961)\end{array}$ & $\begin{array}{c}-11.10 * * \\
(4.838)\end{array}$ & $\begin{array}{c}-10.67^{* *} \\
(4.658)\end{array}$ & $\begin{array}{c}0.250 \\
(0.429)\end{array}$ \\
\hline KAOPEN & $\begin{array}{l}-0.0122 * * \\
(0.00532)\end{array}$ & $\begin{array}{l}-0.00959 * \\
(0.00503)\end{array}$ & $\begin{array}{c}1.018 * * * \\
(0.283)\end{array}$ & $\begin{array}{c}0.938 * * * \\
(0.275)\end{array}$ & $\begin{array}{c}0.0361 \\
(0.0350)\end{array}$ \\
\hline SIZE & $\begin{array}{c}-0.0635 * * * \\
(0.0144)\end{array}$ & $\begin{array}{c}-0.0504 * * * \\
(0.0135)\end{array}$ & $\begin{array}{c}2.073 * * * \\
(0.729)\end{array}$ & $\begin{array}{c}2.063 * * * \\
(0.713)\end{array}$ & $\begin{array}{l}2.565 \\
(2.447)\end{array}$ \\
\hline SHARE & $\begin{array}{c}0.601 * * * \\
(0.170)\end{array}$ & $\begin{array}{c}0.505^{* * *} \\
(0.142)\end{array}$ & $\begin{array}{c}0.174 \\
(8.665)\end{array}$ & $\begin{array}{l}-1.147 \\
(8.710)\end{array}$ & $\begin{array}{l}1.517^{* *} \\
(0.734)\end{array}$ \\
\hline LOANS & $\begin{array}{c}-0.684^{* * *} \\
(0.0475)\end{array}$ & $\begin{array}{c}-0.633^{* * *} \\
(0.0459)\end{array}$ & $\begin{array}{c}3.214 \\
(3.050)\end{array}$ & $\begin{array}{l}2.540 \\
(2.782)\end{array}$ & $\begin{array}{l}-2.361 \\
(2.386)\end{array}$ \\
\hline GDPGR0507 & $\begin{array}{l}0.0125 * * \\
(0.00617)\end{array}$ & $\begin{array}{l}0.0139 * * \\
(0.00581)\end{array}$ & & & \\
\hline RESS & $\begin{array}{l}0.0554^{* *} \\
(0.0237)\end{array}$ & $\begin{array}{c}0.0522 * * \\
(0.0222)\end{array}$ & $\begin{array}{c}-4.670 * * * \\
(1.400)\end{array}$ & $\begin{array}{c}-3.927 * * * \\
(1.370)\end{array}$ & $\begin{array}{l}0.0519 \\
(0.144)\end{array}$ \\
\hline GDPCAP & $\begin{array}{c}-1.72 \mathrm{e}-06^{* *} \\
(8.08 \mathrm{e}-07)\end{array}$ & $\begin{array}{c}-1.92 \mathrm{e}-06 * * * \\
(7.28 \mathrm{e}-07)\end{array}$ & $\begin{array}{c}3.80 \mathrm{e}-05 \\
(4.74 \mathrm{e}-05)\end{array}$ & $\begin{array}{c}3.05 \mathrm{e}-05 \\
(4.43 \mathrm{e}-05)\end{array}$ & $\begin{array}{l}-1.48 \mathrm{e}-06 \\
(5.29 \mathrm{e}-06)\end{array}$ \\
\hline GDPGR0007 & & & $\begin{array}{c}-1.360 * * * \\
(0.444)\end{array}$ & $\begin{array}{c}-1.325^{* * *} \\
(0.417)\end{array}$ & $\begin{array}{c}0.0567 \\
(0.0409)\end{array}$ \\
\hline Constant & $\begin{array}{c}0.651 * * * \\
(0.232)\end{array}$ & $\begin{array}{c}0.771^{* * *} \\
(0.209)\end{array}$ & $\begin{array}{c}31.02 * * * \\
(10.53)\end{array}$ & $\begin{array}{c}29.62 * * * \\
(10.10)\end{array}$ & $\begin{array}{l}-0.176 \\
(1.729)\end{array}$ \\
\hline $\begin{array}{l}\text { Observations } \\
\text { R-squared }\end{array}$ & $\begin{array}{r}238 \\
0.659 \\
\end{array}$ & $\begin{array}{r}238 \\
0.684 \\
\end{array}$ & $\begin{array}{r}205 \\
0.173 \\
\end{array}$ & $\begin{array}{c}207 \\
0.177 \\
\end{array}$ & $\begin{array}{c}173 \\
0.136 \\
\end{array}$ \\
\hline
\end{tabular}

Heteroskedasticity consistent standard errors in parentheses *** $\mathrm{p}<0.01,{ }^{* *} \mathrm{p}<0.05,{ }^{*} \mathrm{p}<0.1$ 
Table A1: Summary Statistics

\begin{tabular}{llllll}
\hline Variable & Obs & Mean & Std. Dev. & Min & Max \\
\hline LIQUID_TA & 238 & .3248649 & .1954829 & .000601 & .9628144 \\
LIQUID_TA0508 & 250 & .3176826 & .1900415 & .000601 & .9608909 \\
LEVERAGE & 215 & 46.76851 & 527.0663 & 1.094968 & 7737.987 \\
LEVERAGE0508 & 217 & 46.41075 & 524.6199 & 1.101905 & 7737.987 \\
ZSCORE & 168 & 3.996603 & 3.481365 & .0615685 & 21.80216 \\
& & & & & \\
DISCL & 238 & 62.42497 & 18.06581 & 4.761905 & 95.2381 \\
SIZE & 238 & 14.26853 & 1.747947 & 8.545911 & 17.76788 \\
SHARE & 238 & .0519788 & .0846086 & 0 & .7403478 \\
LOANS & 238 & .4612948 & .2219005 & 0 & .9892076 \\
FIXEDASSETS & 236 & .0098002 & .0201764 & 0 & .2383549 \\
& & & & & \\
PUBLIC & 238 & .4663866 & .4999202 & 0 & 1 \\
\hline
\end{tabular}

Table A2: Number of banks included in the sample

\begin{tabular}{lr}
\hline Countries & Number of banks \\
\hline Algeria & 14 \\
Egypt, Arab Rep. & 28 \\
Israel & 14 \\
Jordan & 15 \\
Lebanon & 38 \\
Morocco & 14 \\
Oman & 8 \\
Qatar & 11 \\
Saudi Arabia & 13 \\
Syrian Arab Republic & 12 \\
Tunisia & 17 \\
Turkey & 46 \\
United Arab Emirates & 28 \\
\hline & 258 \\
\hline
\end{tabular}

Table A3: Correlation matrix of main explanatory variables

\begin{tabular}{|c|c|c|c|c|c|c|c|c|c|c|}
\hline & DISCL & SIZE & SHARE & LOANS & PUBLIC & $\begin{array}{l}\text { GDPGR } \\
0507\end{array}$ & $\begin{array}{l}\text { GDPGR } \\
0007\end{array}$ & GDPCAP & RESS & KAOPEN \\
\hline DISCL & 1.0000 & & & & & & & & & \\
\hline SIZE & $0.5680^{*}$ & 1.0000 & & & & & & & & \\
\hline SHARE & 0.1321 & $0.5614^{*}$ & 1.0000 & & & & & & & \\
\hline LOANS & $0.2973 *$ & $0.2508^{*}$ & 0.0678 & 1.0000 & & & & & & \\
\hline PUBLIC & 0.4958* & $0.4073 *$ & 0.1948* & $0.3739 *$ & 1.0000 & & & & & \\
\hline GDPGR0507 & $0.3490 *$ & 0.1243 & -0.0300 & $0.3360 *$ & $0.3128 *$ & 1.0000 & & & & \\
\hline GDPGR0007 & $0.2713^{*}$ & 0.0650 & -0.0048 & $0.2864 *$ & $0.3070^{*}$ & $0.9128 *$ & 1.0000 & & & \\
\hline GDPCAP & $0.3497 *$ & $0.1974 *$ & 0.0913 & $0.2659 *$ & $0.3192 *$ & $0.5524 *$ & $0.7122 *$ & 1.0000 & & \\
\hline RESS & $0.1720 *$ & 0.1408 & $0.1679 *$ & $0.2698 *$ & $0.2201 *$ & $0.2263^{*}$ & 0.3936* & $0.6835 *$ & 1.0000 & \\
\hline KAOPEN & $0.2761^{*}$ & 0.1267 & 0.0113 & 0.0478 & 0.0482 & $0.2791 *$ & $0.2653 *$ & $0.4322 *$ & $0.3152 *$ & 1.0000 \\
\hline
\end{tabular}


Table A4: OLS regressions with country dummies

(1) (2) (3) (4)

\begin{tabular}{lccccc} 
VARIABLES & LIQUID_TA & LIQUID_TA0508 & LEVERAGE & LEVERAGE0508 & ZSCORE \\
\hline \multirow{2}{*}{ DISCL } & $0.0776^{* * *}$ & $0.0755^{* * *}$ & $-3.323^{*}$ & $-3.212^{*}$ & 0.293 \\
& $(0.0193)$ & $(0.0187)$ & $(1.906)$ & $(1.807)$ & $(0.221)$ \\
SIZE & $-0.0428 * * *$ & $-0.0411^{* * *}$ & $1.323^{* * *}$ & $1.391^{* * *}$ & $4.834^{*}$ \\
& $(0.00711)$ & $(0.00662)$ & $(0.482)$ & $(0.450)$ & $(2.495)$ \\
SHARE & $0.329 * * *$ & $0.340 * * *$ & 3.210 & 0.486 & $1.348^{*}$ \\
& $(0.0919)$ & $(0.0974)$ & $(7.841)$ & $(7.119)$ & $(0.752)$ \\
LOANS & $-0.680 * * *$ & $-0.646^{* * *}$ & 4.369 & 4.163 & $-4.607^{*}$ \\
& $(0.0519)$ & $(0.0550)$ & $(3.489)$ & $(3.382)$ & $(2.438)$ \\
Constant & $0.910 * * *$ & $0.869 * * *$ & 3.775 & -2.791 & -1.215 \\
& $(0.0949)$ & $(0.100)$ & $(6.493)$ & $(7.611)$ & $(0.892)$ \\
Country dummies & Yes & Yes & Yes & Yes & Yes \\
Observations & 238 & 238 & 207 & 209 & 166 \\
R-squared & 0.747 & 0.730 & 0.334 & 0.358 & 0.262 \\
\hline
\end{tabular}

Heteroskedasticity consistent standard errors in parentheses *** $\mathrm{p}<0.01,{ }^{* *} \mathrm{p}<0.05,{ }^{*} \mathrm{p}<0.1$ 
Table A5: OLS regressions dropping countries one by one ${ }^{\mathrm{a}}$

\begin{tabular}{|c|c|c|c|c|c|}
\hline VARIABLES & $\begin{array}{c}(1) \\
\text { LIQUID_TA }\end{array}$ & $\begin{array}{c}(2) \\
\text { LIQUID_TA0508 }\end{array}$ & $\begin{array}{c}(3) \\
\text { LEVERAGE } \\
\end{array}$ & $\begin{array}{c}(4) \\
\text { LEVERAGE0508 } \\
\end{array}$ & $\begin{array}{c}(5) \\
\text { ZSCORE } \\
\end{array}$ \\
\hline DISCL & $\begin{array}{c}0.0721^{* *} \\
(0.0309)\end{array}$ & $\begin{array}{l}0.0606^{*} \\
(0.0324)\end{array}$ & $\begin{array}{l}-3.785 * \\
(2.225)\end{array}$ & $\begin{array}{l}-3.328 * \\
(1.844)\end{array}$ & $\begin{array}{c}0.165 \\
(0.203)\end{array}$ \\
\hline KAOPEN & $\begin{array}{c}-0.0277 * * * \\
(0.00624)\end{array}$ & $\begin{array}{l}-0.0260 * * * \\
(0.00607)\end{array}$ & $\begin{array}{l}-0.117 \\
(0.591)\end{array}$ & $\begin{array}{l}-0.171 \\
(0.492)\end{array}$ & $\begin{array}{c}0.0594 \\
(0.0494)\end{array}$ \\
\hline SIZE & $\begin{array}{c}-0.0349 * * * \\
(0.00819)\end{array}$ & $\begin{array}{c}-0.0292 * * * \\
(0.00697)\end{array}$ & $\begin{array}{c}1.871 * * \\
(0.763)\end{array}$ & $\begin{array}{c}1.786 * * * \\
(0.633)\end{array}$ & $\begin{array}{c}1.722 \\
(3.265)\end{array}$ \\
\hline SHARE & $\begin{array}{l}0.300 * * * \\
(0.0982)\end{array}$ & $\begin{array}{l}0.274 * * * \\
(0.0847)\end{array}$ & $\begin{array}{l}-2.095 \\
(10.16)\end{array}$ & $\begin{array}{l}-2.590 \\
(8.797)\end{array}$ & $\begin{array}{l}1.374 * \\
(0.740)\end{array}$ \\
\hline LOANS & $\begin{array}{c}-0.711^{* * *} \\
(0.0485)\end{array}$ & $\begin{array}{c}-0.669 * * * \\
(0.0514)\end{array}$ & $\begin{array}{c}-0.142 \\
(3.431)\end{array}$ & $\begin{array}{l}-0.343 \\
(2.838)\end{array}$ & $\begin{array}{l}-1.704 \\
(3.223)\end{array}$ \\
\hline GDPGR0507 & $\begin{array}{c}0.0281 * * * \\
(0.00611)\end{array}$ & $\begin{array}{l}0.0267 * * * \\
(0.00595)\end{array}$ & & & \\
\hline RESS & $\begin{array}{c}0.0344 \\
(0.0211)\end{array}$ & $\begin{array}{l}0.0365^{*} \\
(0.0213)\end{array}$ & $\begin{array}{c}-5.873 * * * \\
(1.685)\end{array}$ & $\begin{array}{c}-5.029 * * * \\
(1.576)\end{array}$ & $\begin{array}{c}0.112 \\
(0.134)\end{array}$ \\
\hline GDPCAP & $\begin{array}{l}-1.37 e-06 * \\
(7.30 e-07)\end{array}$ & $\begin{array}{c}-1.78 \mathrm{e}-06 * * \\
(7.01 \mathrm{e}-07)\end{array}$ & $\begin{array}{c}4.37 \mathrm{e}-05 \\
(5.10 \mathrm{e}-05)\end{array}$ & $\begin{array}{c}3.47 \mathrm{e}-05 \\
(4.64 \mathrm{e}-05)\end{array}$ & $\begin{array}{l}-1.02 \mathrm{e}-06 \\
(5.15 e-06)\end{array}$ \\
\hline GDPGR0007 & & & $\begin{array}{c}-1.292 * * \\
(0.549)\end{array}$ & $\begin{array}{c}-1.226 * * \\
(0.473)\end{array}$ & $\begin{array}{c}0.0504 \\
(0.0443)\end{array}$ \\
\hline Constant & $\begin{array}{c}0.729 * * * \\
(0.112)\end{array}$ & $\begin{array}{c}0.676^{* * * *} \\
(0.112)\end{array}$ & $\begin{array}{c}7.998 \\
(8.739)\end{array}$ & $\begin{array}{c}7.001 \\
(7.578)\end{array}$ & $\begin{array}{c}0.240 \\
(0.860)\end{array}$ \\
\hline $\begin{array}{l}\text { Observations } \\
\text { R-squared }\end{array}$ & $\begin{array}{c}197 \\
0.725 \\
\end{array}$ & $\begin{array}{c}197 \\
0.717 \\
\end{array}$ & $\begin{array}{r}173 \\
0.219 \\
\end{array}$ & $\begin{array}{c}175 \\
0.244 \\
\end{array}$ & $\begin{array}{c}144 \\
0.119 \\
\end{array}$ \\
\hline
\end{tabular}

Heteroskedasticity consistent standard errors in parentheses

$* * * \mathrm{p}<0.01, * * \mathrm{p}<0.05, * \mathrm{p}<0.1$

a Regression with the largest standard error for the variable "Disclosure" (DISCL) 